\title{
Institutional Review Board Independent Ethics Committee Subject Diary
}

National Cancer Institute

\section{Source}

National Cancer Institute. Institutional Review Board Independent Ethics Committee

Subject Diary. NCI Thesaurus. Code C115588.

An instrument approved by the Institutional Review Board (IRB)/Independent Ethics

Committee (IEC) that is used to record subject data away from a clinical trial site. 